\title{
Obituary
}

\section{Dale Martin Heien \\ (August 20, 1936 - June 19, 2009)}

Dale Heien lived a full and diverse life as an applied economist, family man, and wine grape grower. His career as an economist had three main phases. After completing his $\mathrm{PhD}$ at George Washington University in 1967, Dale worked for a few years at the U.S. Bureau of Labor Statistics in Washington D.C. before spending almost 10 years as a private economic consultant, and then 24 years as an academic. Dale taught in the Department of Economics at San Jose State University (1979-80), before taking up professorial positions in the Department of Agricultural Economics at Pennsylvania State University (1980-1982), and the Department of Agricultural and Resource Economics at UC Davis (1982-2003).

Throughout his career in government service, in the private sector, and in university teaching and research, Dale published articles in top-ranked economics and statistics journals such as Econometrica, the Journal of the American Statistical Association, the Review of Economics and Statistics and the Journal of Political Economy, as well as a long list of articles in the American Journal of Agricultural Economics. He also contributed to the Journal of Wine Economics. Dale's body of published work is acclaimed for its hallmark of high-quality applied econometrics with a focus on consumer behavior. His early work emphasized modeling complete systems of demand equations, and he made a number of contributions to the literature in this area as well as to the broader subject of demand analysis. He also contributed more generally to the academic literature across topics including cost of living indexes; productivity measurement; consumer welfare measurement; competition and price determination in the food industry; and a large number of studies of markets and policies for particular commodities.

In parallel with his career in teaching and research at Davis, Dale was a commercial wine grape grower in the Napa Valley. His interest in wine as a producer and consumer was eventually matched with a shift in the focus of his academic work. In the years before he retired from the university in 2003, Dale conducted economic studies of the markets for wine and wine grapes, the economic and health consequences of alcohol consumption, and the regulation of markets for alcoholic beverages. 
Dale was born August 20, 1936 in Danville, Illinois and he died at age 72 on June 19, 2009. He is survived by his wife Kathryn and his children, Eric Heien of Osaka, Japan, Alex Heien of San Rafael, California, and Elisabeth Heien of Irvine, California. Memorial donations may be made to the Friedman Foundation for Educational Choice at http://www. friedmanfoundation.org/Welcome.do or the Alzheimer's Association at http://www.alz. org/join_the_cause_donate.asp

Julian Alston

University of California, Davis 